\title{
Creutzfeldt-Jakob Disease: Report of Four Cases and Review of the Literature
}

\author{
Creutzfeldt-Jakob Hastalığı: \\ Dört Olgunun Sunumu ve Literatürün Gözden Geçirilmesi
}

Fatma ÖZ ATALAY', Şahsine TOLUNAY', Gonca ÖZGÜN' ', Ahmet BEKAR², Mehmet ZARifoĞLU³

Departments of ${ }^{1}$ Pathology, ${ }^{2}$ Neurosurgery and ${ }^{3}$ Neurology, Uludağ University, Faculty of Medicine, BURSA, TURKEY

\begin{abstract}
Creutzfeldt-Jakob disease is a very rare, progressive neurodegenerative disorder that is incurable and always fatal. It is one of the transmissible spongiform encephalopathies caused by prions. Multiple vacuoles in neuropil and neuronal loss in the gray matter gives the classical sponge-like appearance of brain and are responsible for the typical clinical symptoms.

In this report, we present 4 cases referred to the neurology department of Uludağ University with neurological symptoms. Patients were evaluated with electroencephalogram and magnetic resonance imaging, and performed brain biopsies for further investigation. For definitive diagnosis of Creutzfeldt-Jakob disease, accumulation of prion protein in brain was detected immunohistochemically. Patients died within weeks in consequence of rapid progression of the disease.

Although Creutzfeldt-Jakob disease is an infrequent disorder, when a patient presents with characteristic clinical symptoms such as rapidly progressive dementia with myoclonus, the diagnosis of Creutzfeldt-Jakob disease should be taken into consideration.
\end{abstract}

Key Words: Creutzfeldt-Jakob disease, Spongiform encephalopathy, Prion protein

\section{INTRODUCTION}

Creutzfeldt-Jakob disease (CJD) is a fatal, transmissible neurodegenerative disease in humans caused by a slow infectious protein agent-designated prion. It occurs worldwide and has a prevalence of approximately one death per million per annum (1).

Although, it is usually sporadic, it has a familial pattern in about $10-12 \%$ of the cases, presenting as an autosomal dominant inheritance (2). It is recognized as a dominantly contagious or communicable disease, but it is of special importance because it is inevitably fatal and has been iatrogenically transmitted to patients and possibly to

(Turk Patoloji Derg 2015, 31:148-152)

Received : 24.08.2011 Accepted : 25.10.2011

\section{ÖZ}

Creutzfeldt-Jakob hastalığ 1 çok nadir görülen, tedavisi olmayan ve her zaman ölümcül seyreden ilerleyici nörodejeneratif bir hastalıktır. Prionların sebep olduğu bulaşıcı spongiform ensefalopatilerden biridir. Gri cevherde nöron kaybı ve nöropilde yer alan çok sayıdaki vakuol beyinin klasik sünger benzeri görünümü almasından ve tipik klinik semptomların ortaya çıkmasından sorumludur.

Bu yayında, Uludağ Üniversitesi Nöroloji Bölümüne nörolojik semptomlar nedeniyle başvuran 4 olguyu sunduk. Elektroensefalografi ve manyetik rezonans görüntüleme ile değerlendirilen hastalara daha ileri araştırma için beyin biyopsisi uygulandı. Creutzfeldt-Jakob hastalığının kesin tanısı için beyindeki prion proteini birikimi immünohistokimyasal çalışma ile gösterildi. Kısa bir süre sonra hastalığın hızlı seyri sonucu hastalar kaybedildi.

Myoklonusla birlikte hızlı ilerleyici demans gibi karakteristik klinik semptomlarla başvuran hastalarda, çok nadir görülse de Creutzfeldt-Jakob hastalı̆̆ı mutlaka akla gelmelidir.

Anahtar Sözcükler: Creutzfeldt-Jakob hastalı̆̆ı, Spongiform ensefalopati, Prion protein

medical staff as well. Here we report 4 cases of sporadic CJD which were proven by brain biopsies histopathologically.

\section{CASE REPORTS}

Case 1

A forty-four year old bedridden woman was referred to our institute with preliminary diagnoses of neurodegenerative disease or slow virus infection. Her symptoms had started with headache 4 months ago and progressed rapidly with myoclonic jerks, failure of swallowing reflex, gait disturbances and lack of coordination within 3 weeks. Her magnetic resonance imaging (MRI) studies showed

Correspondence: Fatma ÖZ ATALAY

Uludağ Üniversitesi, Tip Fakültesi, Patoloji Anabilim Dalı, BURSA, TURKEY

E-mail: fzatalay@gmail.com Phone: +90 5055400786 
minimal hyperintensity in deep white matter of the left frontal lobe detected on T2-weighted sequences and fluid-attenuated inversion recovery (FLAIR) MRI led the radiologist to consider gliotic changes. A new MRI performed in our hospital showed dilatation in central cerebrospinal fluid areas secondary to brain atrophy. Her first electroencephalography (EEG) was suggestive of slow virus infection whereas the following EEG was interpreted to be compatible with encephalopathy. When 14-3-3 protein was detected in the cerebrospinal fluid (CSF), brain biopsy was performed to ensure the diagnosis. The patient died as a consequence of respiratory insufficiency 6 months after the onset of symptoms.

\section{Case 2}

A seventy-five year old woman presented to the neurology department of our institute with deterioration of general health status and stupor. Her first complaint was dizziness that had started 6 months ago. She was diagnosed as Parkinson's disease and dementia in two different centers. Meanwhile, rigidity of upper extremity, myoclonus in arms and legs and hallucinations had occurred in a short period. These symptoms were considered to indicate acute dystonia due to the side effects of medications used for dementia. She came to the emergency department with loss of consciousness. Triphasic slow waves were seen on EEG examination. MRI findings were interpreted as hydrocephaly or changes of ischemia that were expected due to her age. There were no infectious agents in the CSF. Brain biopsy was performed to diagnose the disease. The patient died because of cardiac arrest 2 weeks after admission to our institute.

\section{Case 3}

A fifty-seven year old woman who suffered from aggressiveness and lack of communication for 2 years had heat intolerance and weight-loss without loss of appetite. Emotional agitation, delirium and dementia developed rapidly, and she was referred to our institute. EEG revealed normal activity. Cranial MRI studies of the patient performed one month after the onset of the dementia showed strongly marked cerebral cortical sulcus, abnormal hyperintensities in the left nucleus lentiformis on T2-weighted and FLAIR images. She also had fever that decreased with amoxicillin-clavulanic acid administration. The blood tests for the infectious diseases were negative. Brain biopsy was performed to explain the hyper-intensities in the basal ganglia. She experienced sudden respiratory insufficiency and died one month after her hospitalization.

\section{Case 4}

A sixty-two year old woman had been suffering loss of appetite, weakness and right upper quadrant pain for two months. While she was investigated for her gastrointestinal symptoms, she mentioned vertigo and hallucinations. 2 months after her first symptom, she had speech problems and difficulties in walking and standing. Waking EEG studies revealed diffusely active theta and delta activity that was supportive for encephalopathy and she was hospitalized. There were confluent expansive hyperintensities in the periventricular and supraventricular white matter and subcortical white matter on T2-weighted and FLAIR MRI studies. A brain biopsy was performed. Within 3 months of the onset of symptoms, the patient died due to respiratory failure.

\section{Neuropathologic examination}

In gross sections, the biopsies were fragmented grey-white brain tissues. Excisional brain biopsies were performed and put in $10 \%$ formalin fixation for 24 hours followed by the preparation of 5 micrometer-thick, paraffin-embedded sections. For routine neuropathologic examination, sections were stained with haematoxylin and eosin ( $\mathrm{H} \& \mathrm{E})$ and immunostained against prion protein $(\mathrm{PrP})$ using the monoclonal antibody 12F10 (dilution 1:250) that binds to a region of human PrP downstream of the neurotoxic domain adjacent to helix region residues. Immunohistochemistry for $\operatorname{PrP}$ was carried out on deparaffinized and rehydrated sections immersed in $98 \%$ formic acid for one hour.

On microscopic examination, widespread spongiform degeneration characterized by large confluent vacuoles of varying sizes in the neuropil of the cerebral cortex, pink neuronal changes in the neurons, and gliosis in the cortical grey matter were seen all four cases (Figure 1). Although the cerebral white matter was well preserved and without myelin pallor, some mild gliosis were observed. Pathologic diagnoses were confirmed by the Neurology Institute of Vienna University by immunohistochemically demonstrating the synaptic accumulation of $12 \mathrm{~F} 10$ prion protein (Figure 2). Glial fibrillary acidic protein was positive in areas of reactive astrocytosis. Florid plaques, kuru plaques, senile plaques, neurofibrillary tangles or Lewy bodies were not observed. There were no vascular lesions.

\section{DISCUSSION}

CJD is one of the transmissible spongiform encephalopathy diseases caused by a prion. The prion causes normal proteins to fold abnormally. This affects the other proteins' ability to function. 


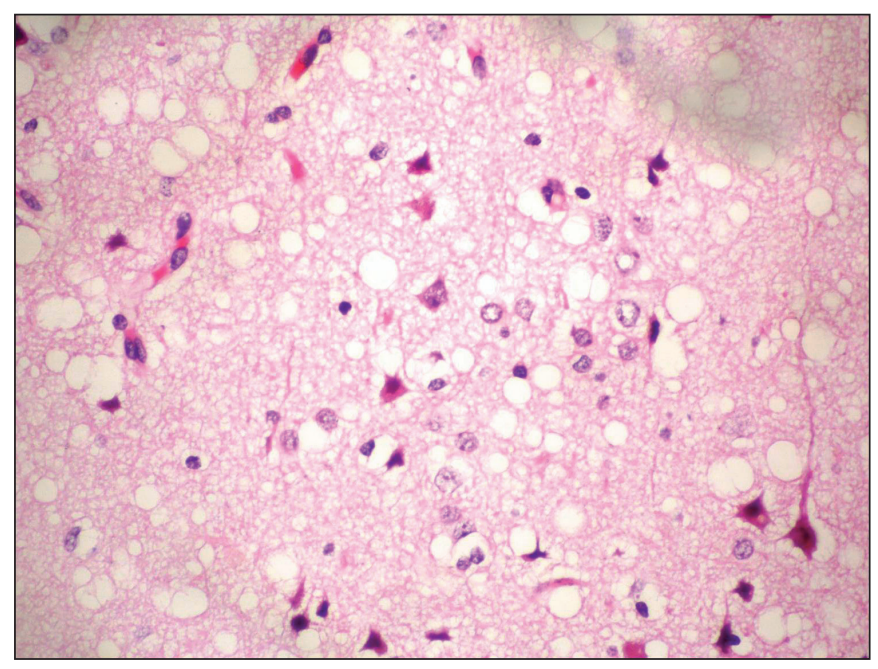

Figure 1: Vacuolization in the neuropil, neuronal loss, pink neuronal changes in the neurons (H\&E x400).

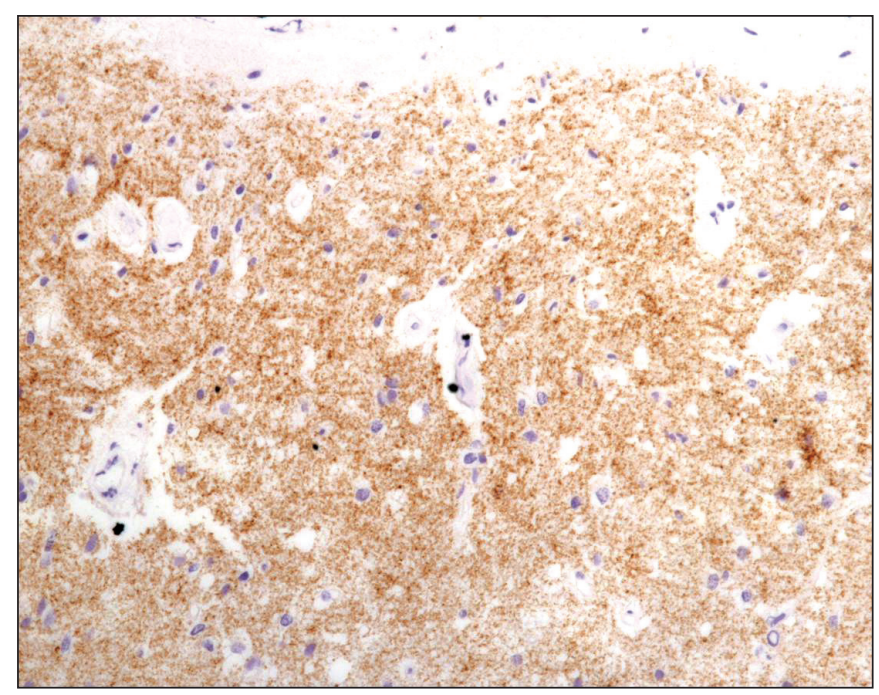

Figure 2: Diffuse synaptic deposition of $\operatorname{PrP}$ in grey matter immunohistochemically (x200).

Four subtypes of CJD have been described to date including familial CJD, iatrogenic CJD, sporadic CJD and variant CJD. Familial CJD is linked to germline mutations of the PrP gene. Iatrogenic CJD, a transmissible form of the disease, is acquired from growth hormone from pooled pituitary glands or cadaver, dura mater grafts, or corneal transplantation. Sporadic CJD (sCJD), the commonest form of the disease, may arise as a result of random mutation or post-translational modification of the PrP gene. In addition, a new type of CJD, namely variant CJD, has been described in the United Kingdom (3). Variant CJD differs significantly from previously described subtypes of the disease in having a younger age of onset, a prolonged duration of disease, a psychiatric presentation of the disease, and the absence of typical EEG features. Variant CJD has been linked to the consumption of meat from cattle with bovine spongiform encephalopathy (4).

The evolution of clinical symptoms and signs are the basis for the diagnosis of sporadic CJD. It usually occurs in middle and old age, and typically affects patients in the seventh decade of life. There are no specific symptoms at the onset of the disease. Most often, depressive personality changes, sleep disorders, and loss of weight occur. Impairment of cognitive functions or behavioral abnormalities are key symptoms and are found in most patients (5). The disorder is fatal in short duration. Generally the causes of death are infection, heart failure, or respiratory failure usually within months. The clinicopathologic presentation of SCJD is influenced by several factors, including the prion strain and polymorphism of the PrP gene of the patient. Analyses of neuropathologic findings as well as of clinical features will provide a better understanding of such factors (6). It has been proposed to classify CJD into six different subgroups (MM1, MM2, MV1, MV2, VV1, and VV2) to identify and understand the major disease groups (7). Although such classification systems are helpful in understanding major sCJD subgroups, there remain individual cases that prove difficult to classify on this basis (8).

Because of the nonspecific symptoms, Alzheimer disease (AD) and dementia with Lewy bodies are considered the most important differential diagnoses in elderly patients. Their rapid disease course, in particular, can rarely be discriminated from CJD when myoclonus is present. On histopathological examination, occurrence of diffuse cortical vacuolization in $\mathrm{AD}$ and superficial cortical vacuolization in fronto-temporal dementia cause difficulty in diagnosis. Thus, further detailed clinicopathologic investigations of sCJD are needed (8). The detection of the 14-3-3 protein in CSF and strong deposits of $\mathrm{PrP}$ in brain tissue help to elucidate the exact diagnosis of sporadic CJD (5). We used the WHO 1998 criteria for the diagnosis of sCJD (Table I) (9).

Variable degrees of neuropathologic involvement are observed in the cerebral neocortex, subiculum, striatum, thalamus and cerebellar cortex, whereas the globus pallidus, hippocampus and dentate gyrus, brainstem and spinal cord are relatively spared $(10,11)$. Neuropathologic hallmarks of SCJD include spongiform change in the neuropil, neuron loss, intense reactive astrocytosis and deposition of abnormal protease-resistant protein in the form of synaptic-type deposits (6).

There is no generally accepted treatment for CJD and the disease is invariably fatal but early diagnosis and 
Table I: WHO 1998 criteria for diagnosis of sCJD

\begin{tabular}{|c|c|}
\hline Definite sCJD & $\begin{array}{l}\text { Diagnosed by standard neuropathologic tecniques and/or immunohistochemistry and/or western } \\
\text { blot confirmed } \operatorname{PrP} \text { and/or presence of scrapie-associated fibrils }\end{array}$ \\
\hline Probable sCJD & $\begin{array}{l}\text { Progressive dementia } \\
\text { At least } 2 \text { of the following symptoms: } \\
\text { - Myoclonus } \\
\text { - Pyramidal/extrapyramidal } \\
\text { - Visual } \\
\text { - Akinetic mutism } \\
\text { Positive EEG } \\
\text { and/or positive } 14-3-3 \text { protein result and }<2 \text { year disease duration } \\
\text { Routine investigations do not suggest an alternative diagnosis }\end{array}$ \\
\hline Possible sCJD & $\begin{array}{l}\text { Progressive dementia } \\
\text { At least } 2 \text { of the following symptoms: } \\
\text { - Myoclonus } \\
\text { - Pyramidal/extrapyramidal } \\
\text { - Visual } \\
\text { - Akinetic mutism } \\
\text { No supportive EEG }\end{array}$ \\
\hline Genetic CJD & Identified PRNP mutation or symptomatic with positive family medical history \\
\hline Iatrogenic CJD & $\begin{array}{l}\text { Meets critieria for sCJD } \\
\text { Positive medical history of CJD exposure via contaminated surgical instruments (e.g., human } \\
\text { cadaveric-derived growth hormone, corneal transplant) }\end{array}$ \\
\hline
\end{tabular}

WHO; World Health Organisation, CJD; Creutzfeldt-Jakob disease, EEG; electroencephalography, PRNP; PRioN Protein.

treatment may make the symptoms easier to control. The most important issue is prevention as prions have been transmitted to patients and possibly to the medical staff as well. Mechanisms of natural transmission of human CJD are not understood except for iatrogenic cases. The agents are highly resistant to complete inactivation by exposure to heat, ultraviolet and ionizing radiation, or a variety of chemicals that disinfect conventional viruses. Precautions are the use of gloves, and maximal protection of people who come into contact with contaminated tissue (e.g. pathologist, histological laboratory worker and neurosurgeons). For laboratory research, the tissue must be submerged in 92-98\% formic acid for 1 hour. All used materials and instruments must be decontaminated using $\mathrm{NaOH}, \mathrm{NaClO}$, guanidine thiocyanate, or steam autoclaving $(12,13)$. In our cases, these specific safety precautions were performed to avoid accidental transmission and to avoid any infectivity.

Our cases had no family history of the disease, did not receive human hormones prepared from pooled pituitary glands or cadaver, did not undergo electrocorticography with a previously used probe electrode, and had not undergone dura mater graft or corneal transplantation, so we eliminated the iatrogenic form CJD and the familial form CJD as well. Our patients were in an older age group at onset and had a shorter clinical history than patients diagnosed with variant CJD. We diagnosed our 4 patients as sporadic CJD with their MRI findings, EEG findings, detection of 14-3-3 protein in the CSF and histologically confluent vacuole-type spongiform change of varying severity in the cerebral cortex. Demonstrating the accumulation of PrP immunohistochemically in brain tissue and also using the WHO 1998 criteria, we grouped our 4 cases into the 'Definite CJD' group.

\section{ACKNOWLEDGEMENT}

We would like to give our very special thanks to Prof. Dr. Herbert Budka, director of Neurology Institute of Vienna University, who kindly provided immunohistochemical studies of our cases. 


\section{REFERENCES}

1. Aguzzi A, Heikenwalder M, Miele G. Progress and problems in the biology, diagnostics, and therapeutics of prion diseases. J Clin Invest. 2004;114:153-60.

2. Belay ED. Transmissible spongiform encephalopathies in human. Annu Rev Microbiol. 1999;53:283-314.

3. Will RG, Ironside JW, Zeidler M, Cousens SN, Estibeiro K, Alperovitch A, Poser S, Pocchiari M, Hofman A, Smith PG. A new variant of Creutzfeldt-Jakob disease in the UK. Lancet. 1996; 347:921-5.

4. Armstrong RA. Laminar distribution of the pathological changes in sporadic and variant Creutzfeldt-Jakob disease. Patholog Res Int. 2011;236346.

5. Zerr I, Poser S. Clinical diagnosis and differential diagnosis of CJD and vCJD. With special emphasis on laboratory tests. APMIS. 2002;110:88-98.

6. Iwasaki Y, Yoshida M, Hashizume Y, Kitamoto T, Sobue G. Clinicopathologic characteristics of sporadic Japanese Creutzfeldt-Jakob disease classified according to prion protein gene polymorphism and prion protein type. Acta Neuropathol. 2006;112: 561-71.

7. Parchi P, Giese A, Capellari S, Brown P, Schulz-Schaeffer W, Windl O, Zerr I, Budka H, Kopp N, Piccardo P, Poser S, Rojiani A, Streichemberger N, Julien J, Vital C, Ghetti B, Gambetti P, Kretzschmar H. Classification of sporadic Creutzfeldt-Jakob disease based on molecular and phenotypic analysis of 300 subjects. Ann Neurol. 1999;46:224-33.
8. Niimi Y, Iwasaki Y, Umemura T, Tanaka F, Yoshida M, Hashizume Y, Kitamoto T, Hirayama M, Sobue G. MM2-cortical-type sporadic Creutzfeldt-Jakob disease with early stage cerebral cortical pathology presenting with a rapidly progressive clinical course. Neuropathology. 2008;28:645-51.

9. Global Surveillance, Diagnosis and Therapy of Human Transmissible Spongiform Encephalopathies: Report of a WHO Consultation. Geneva, Switzerland, 9-11 February 1998.

10. Hoshino A, Iwasaki Y, Izumi $M$, Kimura $S$, Ibi $T$, Kitamoto T, Yoshida M, Hashizume Y, Sahashi K. MM1-type sporadic Creutzfeldt-Jakob disease with unusually prolonged disease duration presenting with panencephalopathic-type pathology. Neuropathology. 2008;28:326-32.

11. Iwasaki Y, Yoshida M, Hashizume Y, Kitamoto T, Sobue G. Neuropathologic characteristics of spinal cord lesions in sporadic Creutzfeldt-Jakob disease. Acta Neuropathol. 2005;110:490-500.

12. Gajdusek DC, Gibbs CJ Jr, Asher DM, Brown P, Diwan A, Hoffman P, Nemo G, Rohwer R, White L. Precautions in medical care of, and in handling materials from, patients with transmissible virus dementia (Creutzfeldt-Jakob disease). N Engl J Med. 1977;297: 1253-8.

13. Brown P, Wolff A, Gajdusek DC. A simple and effective method for inactivating virus infectivity in formalin-fixed tissue samples from patients with Creutzfeldt-Jakob disease. Neurology. 1990; 40: 887-90. 